\title{
Approaching Pythagoras of Samos : Ritual, natural philosophy and politics
}

\author{
Riedweg, Christoph
}

\begin{abstract}
The following paper adopts a rather peculiar three-step approach: Starting from general notions about Pythagoreanism and from the impact which Pythagorean ideas have had through the centuries to this day, it then tries to cautiously reconstruct at least some hypothetically authentic traits of the elusive Samian sage and his movement, interpreting the all too scanty evidence against the background of its contemporary Ionian natural philosophy and of modern sociological concepts. Finally, a bold attempt is made to elucidate Pythagoras' bewildering personality from comparable phenomena in today's society which are characterized by a similar blend of rational and irrational elements.
\end{abstract}

Posted at the Zurich Open Repository and Archive, University of Zurich

ZORA URL: https://doi.org/10.5167/uzh-84962

Book Section

Published Version

Originally published at:

Riedweg, Christoph (2013). Approaching Pythagoras of Samos : Ritual, natural philosophy and politics. In: Cornelli, Gabriele; McKirahan, Richard; Macris, Constantinos. On Pythagoreanism. Berlin/Boston: De Gruyter, 47-60. 


\section{Approaching Pythagoras of Samos: Ritual, Natural Philosophy and Politics}

The following paper adopts a rather peculiar three-step approach: Starting from general notions about Pythagoreanism and from the impact which Pythagorean ideas have had through the centuries to this day, it then tries to cautiously reconstruct at least some hypothetically authentic traits of the elusive Samian sage and his movement, interpreting the all too scanty evidence against the background of its contemporary Ionian natural philosophy and of modern sociological concepts. Finally, a bold attempt is made to elucidate Pythagoras' bewildering personality from comparable phenomena in today's society which are characterized by a similar blend of rational and irrational elements.

\section{Pythagoras in the Occidental Cultural Memory}

Who would not know him, Pythagoras of Samos? Like an Orpheus, Plato or Aristotle he undoubtedly belongs to those figures from Antiquity that have become stock ingredients of our cultural memory, and about whom everybody has at least some vague ideas.

Hearing his resounding name, one cannot help thinking of $a^{2}+b^{2}=c^{2}$, the famous theorem which indeed is fundamental for mathematics and according to which "in a right-angled triangle the [square of the] hypotenuse is equal to the [squares of the] other two sides" (Diog. Laert. 8,12). ${ }^{1}$

As for me, however, I arrived at Pythagoras less through mathematics than through music. For Pythagoras is also supposed to have discovered the numerical value of the basic consonances (octave, fifth, fourth) and to have applied this important insight to the entire cosmos. A fascinating concept - the world

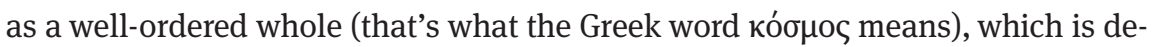
signed along the same construction principles as the musical consonances, and which therefore produces a magnificent harmony. ${ }^{2}$

1 As modern research has evinced, it was already practised by the Babylonians even if it seems not to have been formulated explicitly as a theorem; see Burkert 1972, p. 428 f.; Pichot 1995, p. $80-85$ and 360 f.; Riedweg 2008, p. 90; cf. in general now also Hoehn \& Huber 2005 and Maor 2007.

2 Cf. Aristot. Met. 986a2 s.; Xenocr. fr. 9 Heinze $=87$ Isnardi. General treatments of Pythagorean cosmology include Burkert 1972, p. 465 ff.; Kahn 2001, p. 24 ff.; Riedweg 2008, p. 27 ff. and $110 \mathrm{ff}$. 
No wonder the Pythagorean idea of the Harmony of the Spheres has been inspiring the human imagination throughout the centuries, from the Middle Ages all through the Renaissance and the early modern period up till today. ${ }^{3}$

For sure, such an idea may already go beyond the realm of 'hard' sciences, although one should not forget that someone like Johannes Kepler, the founder of the classical natural sciences, was driven by a genuinely Pythagorean enthusiasm when he discovered the third law of planetary motion: He wanted nothing else than to track down the harmony that resounded at the very moment of the divine creation of the world. ${ }^{4}$

Incidentally, the notion that at least some stars produce a kind of cosmic music gets support from recent astronomical discoveries: according to the two Swiss astronomers François Bouchy and Fabien Carrier, ${ }^{5}$ the surface of the sunlike star Alpha Centauri A in the galaxy is vibrating periodically (as the sun has for long been known to do it). The vibrations are caused by sound waves in the star's interior which owe their origin to nuclear reactions and which, upon hitting the surface, make it vibrate like a tambourine. We are unable to hear this starry music, because the waves cannot spread out into interstellar space; moreover, the frequency would be out of our audible range. These observations show some striking parallels to Pythagorean teachings: as Aristotle reports, the Pythagoreans were convinced that stars, being swiftly moving massive bodies, must necessarily produce a sound, and since they revolve at distances and speeds proportional to each other and in keeping with the proportions of the musical harmonies, the revolution of the stars produces a harmonious sound. ${ }^{6}$ Whereas we ordinary human beings, due to the limits of our nature, are unable to hear this harmony, Pythagoras, extraordinarily gifted as he was, would have perceived the overall harmony of the spheres and transmitted it as much as possible to his pupils, using instruments and his voice. ${ }^{7}$

Kepler at any rate has been termed "the German Pythagoras" for good reason. From him, a line may be drawn through Leibniz to Harmonical Pythagoreanism - a movement of the 20th century, whose main protagonist was Hans Kayser, a pupil of Humperdinck and Schönberg, who emigrated with his Jewish

3 Harmony of the Spheres: Burkert 1972, p. 350 ff.; on the tradition, cf. Heninger 1974; Ferguson 2008, p. $215 \mathrm{ff}$.

4 Cf. Kahn 2001, p. 161 ff.; Bialas 2004, p. 144ff.; Schaffer 2004, p. $65 \mathrm{ff}$.

5 Bouchy and Carrier 2002 (cf. Vonarburg 2001).

6 Aristot. De cael. 290b12-29 and 291a7-9, as well as fr. 162, p. 414a, 3-16 Gigon.

7 Porph. VPyth. 30 = Nicom. FGrHist 1063 F 1; Iambl. VPyth. 65f. Cf. O’Meara 2007. 
wife into Switzerland in $1933 .^{8}$ I originally came to know about the Harmonical Pythagoreanism thanks to my music teacher at the boarding-school in Einsiedeln, P. Daniel Meier, a pupil of Hindemith, who enthusiastically shared Kayser's view that the proportions of the harmonics are essential in explaining the growth of crystals as well as in quantum theory. As part of this movement may be counted also an interesting Swiss architect, André Studer, who used to design his buildings by means of the monochord. ${ }^{9}$

Be that as it may, other fascinating ideas seem to definitely place Pythagoras in the corner of esoteric arts. As examples, one might mention his ban on eating beans or the assumption that all living beings are kindred and that the human soul may enter even animal organisms. Vegetarianism results naturally from such an assumption, and in fact the vegetarian movement still refers to Pythagoras as an ancestor. ${ }^{10}$

No doubt, to this day Pythagoras as an idea, as a cultural construct, keeps cropping up in various refractions. His name is not missing in any dictionary of musicology, mathematics and astronomy - not to mention dictionaries of antiquity, freemasonry and esotericism.

\section{II À la recherche du Pythagore perdu}

But who really was he, Pythagoras of Samos, who radiates such a lasting fascination? What can we actually know about him and his teachings today? And how may the different facets of this peculiarly sparkling figure be reconciled?

Questions like these appeared when I started researching on Pythagoras in the late nineties. For a Hellenist, a literary approach imposes itself, and modern tools like the TLG and the PHI latin texts decisively facilitate the labour of collecting and interpreting all the relevant passages in Greek and Roman literature.

Yet, the literary transmission is quite tricky to deal with, as everybody knows. The sources become richer and richer the more we move away from Py-

8 Cf. Kayser 1968 and 1984. Other articles of Hans Kayser have been published in the 'Schriften über Harmonik' series edited by the 'Kreis der Freunde von Hans Kayser' at Bern. See in general Riedweg 2008, p. 173f.; D’Anna 2010, p. $228 \mathrm{ff}$.

9 Studer 1976; 1977, p. 16ff.; 1991, p. 12f.; on Harmonical Pythagoreanism in architecture also Haase 1986. For the earliest references to the monochord in Greek literature see now Creese 2010, p. $97 \mathrm{ff}$.

10 Cf. the proceedings of a conference (originally entitled "Vegetarisch in das neue Jahrtausend - das Vermächtnis des Pythagoras und die Zukunft der vegetarischen Idee”): Linnemann and Schorcht 2001. 
thagoras' life-time (Pythagoras must have been born around $570 \mathrm{BC}$ and may well have lived down into the eighties of the 5th century $\mathrm{BC}$ ). The only continuous accounts that have come down to us from Antiquity date from the 2nd/3rd cent. AD, i.e. roughly 800 years after Pythagoras, a fact that nurtures scepticism about their documentary value. Moreover, they often contain diverging, if not plainly contradictory evidence.

To take vegetarianism as an example, some sources point to a rigid abstinence from eating meat. The brilliant mathematician Eudoxus of Cnidus (c. 390-c. 340 BC) exaggerates Pythagoras' eagerness for ritual purity and his rejection of bloodshed and those who caused it, to the point of claiming that Pythagoras not only abstained from eating animate beings, but also avoided any contact with cooks and hunters. ${ }^{11}$ In contrast to this, there are witnesses, of virtually the same period and of no less weight (Aristotle for instance) who attribute to Pythagoras and his followers only the prohibition of eating certain parts of animals, such as the womb and the heart, as well as several kinds of fish. ${ }^{12}$ Still more bewildering is another document that presents Pythagoras sacrificing on the spot an ox or even a hecatomb of oxen to the Muses in his delight at his discovery of the mathematical theorem. ${ }^{13}$ How does this agree with vegetarianism? And yet another odd piece of information: the story goes that Pythagoras also served as a sports coach and recommended an all-meat diet - with overwhelming success, for the "Samian athlete Eurymenes, although he was small in body, was able, thanks to Pythagoras' wisdom, to defeat many larger [opponents] and won a victory in Olympia" (Porph. VPyth. 15) ...

It is more than obvious, then, that the literary tradition about Pythagoras is extraordinarily polyphonic and dissonant. This uncomfortable situation may, at least partly, be caused by some sociological and historical peculiarities: ${ }^{14}$

a) The Pythagorean community seems to have been sworn to secrecy. ${ }^{15} \mathrm{The}$ pupils were entitled to share the tenets of Pythagoras' doctrine only amongst themselves; and, in fact, at least in the beginning, little seems to have leaked out from the inner circles. The space left empty by this rigid observance of secrecy could easily - and disparately - be filled by outsiders.

b) From the earliest period expressions of the highest admiration for Pythagoras as a teacher are accompanied by extremely disparaging statements about

11 Eudox. fr. 325 Lasserre; on Pythagorean vegetarianism in general, cf. Kahn 2001, p. 9; Riedweg 2008, p. $36 \mathrm{f}$.

12 Cf. Aristot. fr. 157 ff. and 177 Gigon; Burkert 1972, p. 181 ff.; Riedweg 2008, p. 67-71.

13 Apollodorus (of Cyzicus?), FGrHist 1095 F 1c.

14 Cf. also Riedweg 2008, p. x.

15 Cf. Burkert 1972, p. 178 f. 
his personality, which again renders it difficult to make a fair assessment of the Pythagoras phenomenon.

c) The legendary idealization of Pythagoras' life, though visible already in early reports, seems to have been continuously enhanced over the centuries, so that it becomes in the end an almost impossible task to separate 'historical reality' from legends.

d) Pythagoras has repeatedly been monopolized and exploited by different parties over time. A particularly tricky aspect of the whole tradition resides precisely in the fact that the great philosopher Plato was without any doubt profoundly influenced by Pythagoras with regard to central tenets of his thinking (this was clearly stated by Plato's pupil Aristotle). ${ }^{16}$ Since Plato was a towering and extraordinarily creative thinker, it was his variant of philosophy that in the end won out, with devastating consequences for the old tradition about Pythagoras. The genuine Pythagorean heritage was increasingly overlaid with Platonic ideas, which in retrospect makes it virtually impossible to decide with certainty whether individual elements of the transmission indeed go back to Pythagoras himself or rather originated with Plato. ${ }^{17}$

To sum up, an attempt at a scholarly approach to Pythagoras encounters many serious obstacles that are quite hard to overcome. In order not to get completely lost, it seemed absolutely indispensable, when I started writing down the introduction to Pythagoras, to systematically take into consideration also the contemporary cultural and intellectual environment. ${ }^{18}$

Indeed, Pythagoras was born in a time when intellectually astonishing things were happening in the neighboring city of Miletus, where Ionian natural philosophy was being developed. And on his home island Samos architectural and technical masterpieces were being realized, such as the tunnel of Eupalinus, which is still hailed as an "unsurpassed feat of engineering". ${ }^{19}$ This tunnel, 1'036 meters long and devised to guarantee a long-term water supply, was dug from both ends in order to shorten the construction time - a venture which required substantial mathematical and technical skills, particularly since problems with the stability of the rock and an influx of water had to be dealt with (the problem-

16 Arist. Metaph. A6, 987b11ff.

17 For a general view see Boyancé 1966; Burkert 1972, p. 83ff.; Kahn 2001, p. 14f.; 49-62; Riedweg 2008, p. $20 \mathrm{ff}$. and 116ff.; Périllié 2008, with in particular Szlezák 2008, and now Huffman in this volume.

18 Riedweg 2008, p. $44 \mathrm{ff}$.

19 On this tunnel, cf. Hdt. 3,60; Kienast 1995, p. 187; now also Grewe 2010, p. 144 ff. On Samos in general, see Shipley 1987, p. $74 \mathrm{ff}$. 
atic zone in the mountain was bypassed with an aqueduct tunnel in the shape of an isosceles triangle).

Another city with flourishing culture and civilization was Croton in southern Italy, where Pythagoras moved around $530 \mathrm{BC}$ - allegedly because he wanted to escape Polycrates' tyranny. We read about extremely successful Crotonian doctors, and hardly any other town produced as many Olympic champions as Croton. ${ }^{20}$

Well, this cultural-historical context of a prospering, highly advanced society casts doubts on the image still widespread in the history of philosophy which tends to see Pythagoras almost exclusively as a kind of Guru or Shaman, as an archaic-prescientific sage and religious cathartic priest. ${ }^{21}$ To be sure, there is no doubt that Pythagoras possessed all these qualities too: after his arrival in Croton he quickly started gathering followers and founded a politico-religious community, whose influence spread beyond Croton and which was caracterized by a great number of dietary and behavioral rules that scrupulously regulated the daily routine (some of them are elsewhere known from mystery rites). ${ }^{22}$ Not everyone was easily admitted to that group; on the contrary: applicants had to undergo various tests and selection procedures. ${ }^{23}$ From today's point of view, the Pythagorean community, which in the modern age has served as a model for the freemasons, displays the typical features of a 'sect' (in the neutral sense of modern sociology of religions). ${ }^{24}$ The Pythagoreans, like all sects, have been characterised by a) a charismatic founder, b) clear organizational structures, c) a high degree of spiritual integration, d) elitist feeling ('us' against 'them'), e) measures against apostates. ${ }^{25}$

Yet for all this, it would be one-sided to deny a priori that there was any 'scientific' element in Pythagoras' thought. On a close analysis of the texts, his thinking - as far as we may gather it from the fragmentary transmission - rather shows the typical traits of the progressive philosophy of nature of his time. Like the Milesians Anaximander and Anaximenes as well as other 'Presocratics', he, too, seems to have been driven by an indomitable desire to know (iotopí $\alpha$ ), ${ }^{26}$ and

20 Giangiulio 1989, p. 99-130; Mann 2001, p. 164-191; Kahn 2001, p. 6 f.

21 Cf. Burkert 1972, p. $162 \mathrm{ff}$.

22 Cf. Iambl. VPyth. 138; Burkert 1972, p. $177 \mathrm{f}$.

23 Cf. also Iambl. VPyth. $71 \mathrm{f}$.

24 For these features, see Wilson 1970 and Rudolph 1979.

25 Cf. Burkert 1982; Kahn 2001, p. 83; Riedweg 2008, p. 100-104.

26 Cf. Heraclitus 22 B 129 D.-K. On the importance of the term iotopí $\alpha$ in Ionian cultural context see Burkert 1972, p. 210. Huffman (2008) is, of course, right in arguing that the term as such is not limited to natural philosophy, but "is a general word for enquiry that does imply an active curiosity and desire to know things” (p. 23; he, however, strangely didn’t notice that Riedweg 


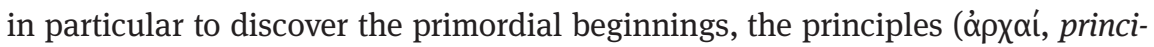
pia) of all things. ${ }^{27}$ But instead of air, 'water and earth', fire or the (materially conceived) 'infinite' (ärcıрov), it was, interestingly enough, 'number' that in the school of Pythagoras was proposed as 'principle' or as the (still materially understood) primary substance: from number originated everything in this world (even heaven itself), and out of number it will continue to exist - that's how the basic assumption runs, an assumption that hasn't lost any of its fasci-

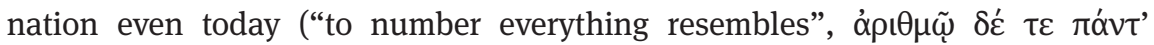

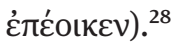

That said, the method of natural philosophical explanation - and this again strikes us as rather strange - remains tightly connected with mystical tendencies. Numbers are partly equated with divinities and thus venerated almost religiously. To give an example, the number 7 is identified with Athena, ${ }^{29}$ since 7 can be considered something like a parthenogenetic prime number: it cannot be generated from any of the first 10 numbers, nor does it produce any of them. ${ }^{30}$ It is obvious that structural analogies between numbers and things were decisive for such identifications. The Pythagoreans seem to have attributed to numbers

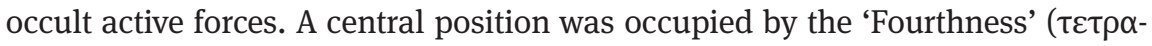
ктús), i. e. the series of the first four numbers. ${ }^{31}$ Adding 1, 2, 3 and 4, one arrives at the number 10, which was considered to be the 'perfect' number; ${ }^{32}$ and visualized by pebbles, the 'Fourthness' builds the "perfect isosceles triangle":

[2008, p. 50] is saying the same thing: "the kind of curiosity that characterized the Ionian natural philosophers as well as the first 'historians,' who acquired their knowledge by traveling and questioning local informants”; see also Riedweg 1997, p. 81f. and 2004, p. 162-172, and Thom in this volume).

27 Cf. Arist. Metaph. A8, 990a3-5.

28 Sext. Emp. Adv. Math. 7,94; Theo Sm. 99,16; Plut. De an. procr. 1029f.; Iambl. VPyth. 162 (= OF 317 Kern = 705 Bernabé). Cf. Burkert 1972, p. 55; 401 ff.; Riedweg 2008, p. 80 ff.

29 Similarly already in Babylon, see Pichot 1995, p. 92f.; in general Burkert 1972, p. 470.

30 Cf. Arist. fr. 162 Gigon (from Aristotle's lost treatise on the Pythagorean philosophy, parts of which are quoted by Alexander of Aphrodisias' Commentary on the Metaphysics, p. 39 Hayduck). 31 Iambl. VPyth. 162; Sext. Emp. Adv. Math. 7,94. On the tetraktys in general, cf. Delatte 1915, p. 249-268; Burkert 1972, p. 72ff.; Kahn 2001, p. 31-36; Riedweg 2008, p. 82f. and 86 f.

32 Cf. Arist. Metaph. A5, 986a8f. 


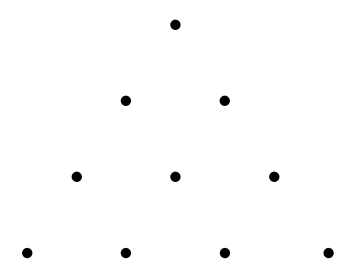

Moreover, the 'Fourthness' also contains the proportions of the basic musical consonances $(2: 1,3: 2,4: 3)$. In an old Pythagorean saying the 'Fourthness' is thus equated with the harmony of the Sirens, which means: with the harmony of the spheres, for also in Plato the Sirens which have been allotted to the individual stars are responsible for the cosmic harmony. ${ }^{33}$

It might well be that it was this peculiar combination of natural philosophy and mythico-religious explanation of the world that caused irritation as early as with Pythagoras' contemporaries. Natural philosophers such as Xenophanes and Heraclitus ridiculed Pythagoras' views (amongst other things in particular his conviction that a human soul may be reincarnated in a puppy dog) and denigrated him in general as a nasty charlatan. ${ }^{34}$

In a completely different mood were the male and female followers, whom Pythagoras must soon have acquired not only in Croton, but also in Metapontum and other cities of southern Italy: according to Aristotle, they attributed to their master a super-human status, ${ }^{35}$ and to confirm this they referred to his many miracles (amongst other things, Pythagoras is said to have predicted earthquakes and to have been able to communicate with animals, as well as to heal friends from their diseases, etc.). ${ }^{36}$

The reactions of those around him were obviously quite contradictory. He thus turns out to be a typical charismatic as defined by the German sociologist Max Weber. For it is characteristic of charismatics that they meet with more or less flat rejection amongst outsiders, or, to quote a modern dictionary of sociology: "We usually do not remain indifferent to a leader whose charisma we do not recognise, but we are inclined to adopt a hostile or contemptuous attitude: we consider him either an imposter or a madman" ${ }^{\prime 3}$ - that is more or less how Her-

33 Plat. Rep. 10, 617b-c.

34 Cf. Xenophanes 21 B 7 D.-K.; Heraclitus 22 B 129 D.-K.; cf. Burkert 1972, p. 209 f.; Riedweg 2008, p. $48 \mathrm{ff}$.

35 I.e., intermediate between humans and god: Arist. fr. 156 Gigon; cf. Riedweg 2008, p. $71 \mathrm{ff}$. 36 Cf. Porph. VPyth. 23-25; 27 f.; Riedweg 2008, p. 2-5.

37 Boudon and Bourricaud 1992, p. 60. 
aclitus felt about Pythagoras. ${ }^{38}$ On the other hand, followers of a charismatic leader ascribe to him special, unusual abilities (“Gnadengaben”, $\chi \alpha \rho i ́ \sigma \mu \alpha \tau \alpha)$. In Pythagoras' case, one may think of the many reports about miracles, which surround him from the earliest times and which often represent him as closely connected to Apollo, the most Greek of all gods, if he is not actually considered to be his incarnation. ${ }^{39}$ According to Max Weber's analysis charismatics always appear to their followers to be super-natural, super-human or at least far from ordinary, ${ }^{40}$ and their charismatic teachings illuminate and give sense to the existence of their followers in many respects. ${ }^{41}$ This again can be amply illustrated with Pythagorean examples: it is sufficient to refer to vegetarianism and the various dietary taboos, but there is also the community of property practised within the group, the importance of friendship, of music and eschatological teachings, etc.

\section{Today's Pythagoras}

No doubt, from a modern point of view Pythagoras and his teachings strike us on the whole as a bewildering phenomenon. The strange combination of rational and irrational explanation of the whole world hardly corresponds to our own experience of life, to the way we tend to see and assess ourselves. And yet, to boldly breach the gap between Pythagoras and our own reality: does the situation present itself so differently in our days? Take modern politics and economics ${ }^{42}$ as examples: the ruling classes are regularly forced to take decisions with farreaching implications under conditions of uncertainty. They therefore take refuge in consulting companies which operate with pragmatic instructions and patterns of solutions that often are far from being exclusively rational, but also - and necessarily - include emotional, if not downright esoteric elements. This is not to depreciate the booming consultant business (whose protagonists, by the way, may strike the observer as a kind of Pythagorean network ${ }^{43}$ ), but to become

38 See above, p. 54, with n. 34.

39 Cf. Iambl. VPyth. 135; 140.

40 Weber 1922, p. 140.

41 Cf. Lipp 1995, p. 33f.; Macris 2003.

42 Rolf Dobelli 2010 has recently unearthed interesting structural analogies between astrological and economical expertise; cf. also Vogl 2010.

43 It is my impression that at the turn of the Millennium McKinsey people, at least in Swiss economics, assumed a role which earlier had been played by the army, Rotarians or Freemasons (as mentioned above, the latter in fact used to refer to Pythagoras as one of their founding fathers). 
aware of parallels like these and others - which include modern 'mathemagical' $^{\text {'4 }}$ beliefs in the power of algorithms that, according to enthusiasts like Piergiorgio Odifreddi, should soon enable us to calculate even human behaviour ${ }^{45}$ could preserve us from hasty arrogance.

I for one am quite convinced that Pythagoras would fare rather well in our society ${ }^{46}$. The sources, indeed, explicitly confirm that he was extremely successful as a political adviser: having arrived in southern Italy, he is said to have deeply impressed the local population with his charismatic appearance and his ethico-political teachings. The town council of Croton straight-away handed over to him all the different social groups of citizens to be morally educated, and the surrounding cities too are said to have sought Pythagoras' advice. ${ }^{47}$ (According to legend, Pythagoras' teaching even influenced Roman legislation through Numa Pompilius, the second king of Rome $)^{48}$.

The advice which Pythagoras is said to have imparted to the Crotonian elite contains much that remains worth considering to this very day. A leading idea of his political thinking seems to have been the concept - corroborated by numberphilosophy and cosmology - of $\alpha \rho \mu o v i ́ \alpha$ among the various social groups, i. e. the means by which they could 'harmonically' be joined together, in order to guarantee social cohesion. This $\dot{\alpha} \rho \mu$ oví $\alpha$ finds symbolical expression in the advice given to the political ruling class to first of all erect a sanctuary dedicated to the Muses, for the nine Muses form a homogeneous, 'harmonic' body of equals, who achieve among themselves perfect concord. ${ }^{49}$ The Muses therefore act as warrants of the consonance and harmony of all things, and the politicians are invited by Pythagoras to follow their example. Against this background it is hardly surprising that later on Plato is said to have erected a sanctuary to the Muses in his Academy, ${ }^{50}$ and that Archytas of Tarentum, a particularly successful Pythagorean politician and friend of Plato, explicitly states that the right meas-

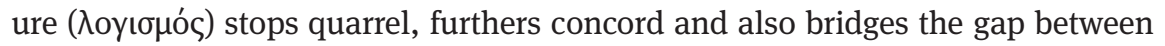
poor and rich. ${ }^{51}$

44 Cf. the illuminating title of the historical novel by Karim El-Koussa (2005), Pythagoras: The Mathemagician.

45 Cf. Odifreddi 2010. Much more critical Kuri 2010.

46 It seems symptomatic to me that his name appears on the cover of a modern sourcebook for counselling and psychotherapy: Howard 2000.

47 Cf. Dicaearch. fr. 40 Mirhady; Kahn 2001, p. 7f.; Riedweg 2008, p. 12 ff. and 60 ff.; also de Vogel 1966, p. $70 \mathrm{ff}$.

48 Cf. Aristox. fr. 17 Wehrli = fr. III 210 Kaiser; Diod. 8,14 etc.; Riedweg 2008, p. 12 and 124.

49 Cf. Iambl. VPyth. 45; Riedweg 2008, p. 13f. and 61.

50 Cf. Boyancé 1966, p. 105f.; Sassi 1988, p. 571 f.

5147 B 3 D.-K. = fr. 3 Huffman. 
Let me add a few other suggestions from Iamblichus' Pythagorean way of life which might be still of some use for politicians and business people. According to this 'Pythagoreanizing' Neoplatonist, Pythagoras gave among others the following pieces of advice (46-49):

- To regard the state as a common pledge, which the leaders have received from the mass of the citizens;

- To be like one's fellow citizens in every way, and to be superior to them only in justice;

- To manage one's own household in an exemplary way, so that it is possible to draw conclusions from this regarding one's political attitude;

- To be a model of discipline and temperance for all, and to avoid sluggishness in action (there is nothing more important than the right moment [Kolpós] for each thing);

- It is the worst injustice to tear asunder children and parents;

- One who seeks honor should emulate the successful runner who does no harm to his opponents, but [only] strives himself to win;

- Everyone should cling to truly good repute and be as he wants to appear to others, etc.

As to the practical conduct of life, one may similarly find useful suggestions in the Pythagorean tradition. A later collection of Pythagorean maxims has not without good reason been labelled the Golden Verses: it is a booklet which enjoyed great popularity already in antiquity and has been repeatedly reprinted in modern times. ${ }^{52}$ Among other things it contains a kind of mental training ( $27 \mathrm{ff}$.): the reader is exhorted to deliberate about everything before acting and

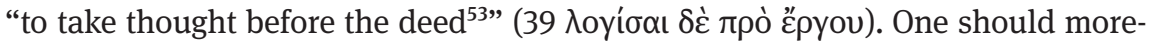
over carry out only things that one really understands and learn all that is necessary, "and thus you will lead a most enjoyable life" (30 f.). Memory training is recommended in the form of recollecting the events of the day before going to sleep, an exercise which clearly resembles the Christian examination of conscience: "Where have I transgressed? What have I accomplished? What duty have I neglected?” (42)

It's time to cut short our little tour through the rich tradition about Pythagoras. I hope it has become evident how a combination of cultural-historical overall perspective with philologically painstaking analysis of texts and modern sociologi-

52 Cf. in general Thom 1995.

53 Translation: Thom 1995. 
cal categories can shed new light on a figure who has lost none of his fascination to this day and who is but one example of how rewarding the intensive study of Antiquity may still prove to be. Pythagoras invites us to ponder over our own society and, multifaceted as he apparently was, he seems particularly apt to bring together the humanities, social and natural sciences, and even politics and economics.

\section{Bibliography}

Bialas, V. 2004. Johannes Kepler. München: Beck'sche Reihe 'Denker'.

Bouchy, F. \& Carrier, F. 2002. "The Acoustic Spectrum of a Cen A", Astronomy \& Astrophysics 390 , p. $205-212$.

Boudon, R. \& Bourricaud, Fr. 1992. Soziologische Stichworte. Ein Handbuch. Opladen: Verlag für Sozialwissenschaften (French original: Dictionnaire critique de la sociologie [“Quadrige”, 303], Paris, PUF, $1994^{2}$ [1982]).

Boyancé, P. 1966. "L'influence pythagoricienne sur Platon", in: Filosofia e scienze in Magna Grecia (Atti del quinto convegno di studi sulla Magna Grecia, Taranto 10-14 ottobre 1965). Napoli: Arte Tipografica, p. 73-113.

Burkert, W. 1972. Lore and Science in Ancient Pythagoreanism. Cambridge (Mass.): Harvard University Press.

Burkert, W. 1982. "Craft Versus Sect: The Problem of Orphics and Pythagoreans," in: B.F. Meyer \& E.P. Sanders (eds.), Jewish and Christian Self-Definition 3: Self-Definition in the Graeco-Roman World. London: SCM Press, p. 1-22 and 183-189 (= Burkert 2006, p. 191-216).

Burkert, W. 2006. Kleine Schriften III: Mystica Orphica, Pythagorica, F. Graf (ed.). Göttingen: Vandenhoeck \& Ruprecht.

Creese, D. 2010. The Monochord in Ancient Greek Harmonic Science. Cambridge: Cambridge University Press.

D’Anna, N. 2010. Da Orfeo a Pitagora. Dalle estasi arcaiche all'armonia cosmica. Roma: Simmetria Edizioni.

Delatte, A. 1915. Etudes sur la littérature pythagoricienne (Bibliothèque de l'Ecole des hautes études, sciences historiques et philologiques, 217). Paris: Champion.

De Vogel, C. J. 1966. Pythagoras and Early Pythagoreanism. An Interpretation of Neglected Evidence on the Philosopher Pythagoras. Assen: Van Gorcum.

Dobelli, R. 2010. "Was Astrologen und Experten für Ökonomie verbindet," Frankfurter Allgemeine Zeitung, 25.10.2010, p. 28.

El-Koussa, K. 2005. Pythagoras: The Mathemagician. Cassville (N)): Cloonfad.

Ferguson, K. 2008. The Music of Pythagoras. How an Ancient Brotherhood Cracked the Code of the Universe and Lit the Path from Antiquity to Outer Space. New York: Walker \& Company.

Giangiulio, M. 1989. Ricerche su Crotone arcaica. Pisa: Edizioni della Normale.

Grewe, K. 2010. Meisterwerke antiker Technik. Mainz: Verlag Philipp von Zabern.

Haase, R. 1986. "Bauen auf dem Fundament der Musik," in: Im Anfang war der Klang: Was ist Harmonik? (Schriften über Harmonik, 16). Bern, p. 57-66. 
Heninger, S. K. Jr. 1974. Touches of Sweet Harmony. Pythagorean Cosmology and Renaissance Poetics. San Marino (Cal.): Huntington Library.

Hoehn, A. \& Huber, M. 2005. Pythagoras: Erinnern Sie sich? Zürich: Orell Füssli.

Howard, A. 2000. Philosophy for Counselling \& Psychotherapy. Pythagoras to Postmodernism. Basingstoke / New York: Palgrave Macmillan.

Huffman, C.A. 2005. Archytas of Tarentum: Pythagorean, Philosopher and Mathematician King. Cambridge: Cambridge University Press.

Huffman, C.A. 2008. “Heraclitus' Critique of Pythagoras' Enquiry in Fragment 129," Oxford Studies in Ancient Philosophy 35, p. 19-47.

Kahn, Ch. H. 2001. Pythagoras and the Pythagoreans. A Brief History. Indianapolis / Cambridge: Hackett Publishing.

Kayser, H. 1968. Die Harmonie der Welt (Beiträge zur harmonikalen Grundlagenforschung, 1). Wien: Lafite.

Kayser, H. 1984. Akróasis. Die Lehre von der Harmonik der Welt. Basel: Schwabe Verlag.

Kienast, H. J. 1995. Die Wasserleitung des Eupalinos auf Samos (Samos, 19). Bonn: Habelt.

Kuri, J. 2010. "Die Welt bleibt unberechenbar," Frankfurter Allgemeine Zeitung, 4. 6. 2010, p. 36.

Linnemann, M. \& Schorcht, C. (ed.) 2001. Vegetarismus. Zur Geschichte und Zukunft einer Lebensweise. Erlangen: Harold Fischer Verlag.

Lipp, W. 1995. “Charisma," in: B. Schäfers et al., Grundbegriffe der Soziologie. Opladen: Leske \& Budrich, p. 33-35.

Macris, C. 2003. "Pythagore, un maître de sagesse charismatique de la fin de la période archaïque,” in: G. Filoramo (ed.), Carisma profetico. Fattore di innovazione religiosa. Brescia: Morcelliana, p. 243-289.

Mann, Ch. 2001. Athlet und Polis im archaischen und frühklassischen Griechenland (Hypomnemata, 138). Göttingen: Vandenhoeck \& Ruprecht.

Maor, E. 2007. The Pythagorean Theorem: A 4000-Year History. Princeton (NJ): Princeton University Press.

Odifreddi, P. 2010. "Benvenuti nell'universo che Pitagora sognò per noi," La Repubblica, 27.3.2010, p. 43.

O'Meara, D. 2007. "Hearing the Harmony of the Spheres in Late Antiquity," in: M. Bonazzi, C. Lévy \& C. Steel (eds.), A Platonic Pythagoras. Platonism and Pythagoreanism in the Imperial Age (Monothéismes et philosophie, 10). Turnhout: Brepols, p. 147-161.

Périllié, J.-L. (ed.) 2008. Platon et les Pythagoriciens. Hiérarchie des savoirs et des pratiques. Musique - Science - Politique. Bruxelles: Ousia.

Pichot, A. 1995. Die Geburt der Wissenschaft. Von den Babyloniern zu den frühen Griechen. Campus: Frankfurt am Main / New York (original publication: La naissance de la science, t. I. Mésopotamie, Égypte, t. II. Grèce présocratique. Paris: Gallimard, 1991).

Riedweg, Chr. 1997. “'Pythagoras hinterliess keine einzige Schrift' - ein Irrtum? Anmerkungen zu einer alten Streitfrage," Museum Helveticum 54, p. 65-92.

Riedweg, Chr. 2004. "Zum Ursprung des Wortes 'Philosophie' oder Pythagoras von Samos als Wortschöpfer,” in: A. Bierl, A. Schmitt \& A. Willi (eds.), Antike Literatur in neuer Deutung. München / Leipzig: K.G. Saur, p. 147-181.

Riedweg, Chr. 2008. Pythagoras. His Life, Teaching, and Influence, 2nd revised ed. Ithaca / London: Cornell Paperbacks (first Engl. ed.: 2005 [see list of corrigenda: http://www. klphs.uzh.ch/aboutus/personen/riedweg/corrigenda_pythagoras_english.pdf]; German 
original: Munich 2002; 2nd revised ed.: 2007; Italian ed. [with a presentation by M.L. Gatti]: Milano 2007).

Rudolph, K. 1979. "Wesen und Struktur der Sekte," Kairos 21, p. 241-254.

Sassi, M. M. 1988. "Tra religione e scienza. Il pensiero pitagorico," in: S. Settis (ed.), Storia della Calabria antica. Roma / Reggio Calabria: Gangemi, p. 565-587.

Schaffer, E. 2004. Die pythagoreische Tradition. Studien zu Platon, Kepler und Hegel (Collegium Hermeneuticum, 10). Köln: Böhlau Verlag.

Shipley, G. 1987. A History of Samos 800-188 B.C. Oxford: Clarendon Press.

Studer, A. 1976. "Architektur - Mensch - Mass," in: Schriften über Harmonik, vol. 2, Bern (reprinted in: Im Anfang war der Klang: Was ist Harmonik? [= Schriften über Harmonik, vol. 16], Bern 1986, p. 67-98).

Studer, A. 1977, Geistige Gestaltungsprinzipien und Sinn der Anwendung der Harmonik in der Architektur (= Schriften über Harmonik, vol. 3), Bern.

Studer, A. 1991. Vernimm das Lied des Alls in dir (= Schriften über Harmonik, vol. 18), Bern.

Szlezák, Th. A. 2008. “Le témoignage d’Aristote,” in Périllié (ed.) 2008, p. 93-115.

Thom, J. C. 1995. The Pythagorean Golden Verses. With Introduction and Commentary. Leiden / New York / Köln: Brill.

Vogl, J. 2010. Das Gespenst des Kapitals. Zürich / Berlin: Diaphanes.

Vonarburg, B. 2001. "Sterne machen kosmische Musik," Tages-Anzeiger, 5. 07. 2001, p. 38.

Weber, M. 1922. Wirtschaft und Gesellschaft. Grundriss der verstehenden Soziologie, First half-volume. Tübingen: Mohr Verlag (reprint 1976).

Wilson, B. 1970. Religious Sects: A Sociological Study. London: Weidenfeld and Nicolson. 